\title{
Effect of Gamma Radiation, EMS and Colchicine on Sprouting in Garlic (Allium sativum L.)
}

\author{
A. P. Pawar ${ }^{1 *}$, V. S. Kale ${ }^{1}$, P. K. Nagre $^{2}$, A. M. Sonkamble ${ }^{1}$ and S. S. Mane ${ }^{3}$ \\ ${ }^{1}$ Department of Vegetable Science, ${ }^{2}$ Faculty of Horticulture, ${ }^{3}$ Department of Plant Pathology, \\ Dr. Panjabrao Deshmukh Krishi Vidyapeeth, Akola- 444104, Maharashtra, India \\ *Corresponding author
}

\section{A B S T R A C T}

\section{Keywords}

Garlic, mutation, Gamma radiation, Ethyl methane sulphonate, Colchicine, Sprouting percent

Article Info

Accepted:

20 August 2020

Available Online:

10 September 2020
A field trial was conducted to study the effect of Gamma Radiation, EMS and Colchicine on Sprouting percentage in garlic variety 'Buldhana local'. The experiment was carried out at Vegetable Instructional farm, Department of Horticulture, Dr. Panjabrao Deshmukh Krishi Vidyapeeth, Akola (M.S.) during Rabi season in the year 2017-2018. It was laid out in Randomized Block Design. The garlic cloves were treated with five levels of gamma radiation $(2,3,4,5$, and 6 Gy), EMS $(0.45 \%, 0.55 \%, 0.65 \%$, $0.75 \%$ and $0.85 \%)$ and Colchicine $(0.08 \%, 0.10 \%$ and $0.12 \%)$ for $12 \mathrm{hrs}$. The study revealed that sprouting percentage decreased with increasing dose of mutagens.

\section{Introduction}

Garlic (Allium sativum L.) is one of the most popular widely cultivated bulbous crop member of Alliaceae family and it's been consumed nearly by every person for various purposes. Garlic is a diploid $(2 \mathrm{n}=2 \mathrm{x}=16)$ predominantly cross fertilizing species. It is originated from the progenitor Allium longicuspis and its centre of origin is Central Asia (Mc Collum, 1976). Garlic has several medicinal properties such as antibacterial (Arora and Kaur, 1999), antifungal (Hughes and Lawson, 1991), antiviral (Meng et al.,
1993), antiprotozoal (Reuter et al., 1996), antioxidant and anticancer properties (Harris et al., 2001).

Mutation breeding is an important tool in crop improvement of vegetatively propagated crops, particularly in plants with reproductive sterility, where this is the only alternative (Broertjes and Harten, 1988). Irradiation of garlic cloves by physical and chemical mutagens is widely used to induce variability at the genetic level which alters number of biochemical processes leading to the desirable changes in the genotype. 
Garlic being a vegetatively propagated crop, posse's low variability. Clonal selection is one of the main methods for garlic improvement (Agrawal et al., 2003), hence it is difficult to create variability to the breeders for selecting the promising genotypes. Consequently, garlic breeding has been limited to the selection of the pre-existing genetic variability and increase in garlic variability was attempted via mutation breeding techniques.

\section{Materials and Methods}

The study entitled "Effect of Gamma Radiation, EMS and Colchicine on Sprouting in Garlic (Allium sativum L.)" was conducted to explore the effect of mutagens in garlic. The Garlic cloves were treated with gamma rays, EMS and colchicine and were planted as per the treatment on $20^{\text {th }}$ October, 2017 in Randomized Block Design with three replications as per the methods suggested by Panse and Sukhatme (1967). Two hundred and fifty cloves were planted under each treatment. The local cultivar Buldhana local was selected with the different doses of gamma rays and was treated at Bhaba Atomic Research Centre, Trombay, Mumbai and chemical treatment with Ethyl Methyl Sulphonate (EMS) and Colchicine was carried out at Horticulture Analytical Laboratory, Department of Horticulture, as an experimental material for the $\mathrm{VM}_{1}$ generation. The cloves were treated with different concentrations of EMS and Colchicine by immersing in EMS and Colchicine solution for 12 hours. After the treatment, these cloves were kept under running tap water for 1 hour to remove adjuvant to the cloves. Thereafter, these were planted in the experimental field at spacing of $15 \times 10 \mathrm{~cm}$. Data recorded on different parameters was analysed statistically to express the results.

\section{Treatment details}

\begin{tabular}{|c|c|c|c|c|c|}
\hline Treatment & $\begin{array}{c}\text { Dose of } \\
\text { gamma rays }\end{array}$ & Treatment & $\begin{array}{c}\text { Dose of } \\
\text { gamma rays }\end{array}$ & Treatment & $\begin{array}{c}\text { Dose of gamma } \\
\text { rays }\end{array}$ \\
\hline $\mathbf{T}_{\mathbf{1}}$ & $2 \mathrm{~Gy}$ & $\mathrm{~T}_{6}$ & $0.45 \% \mathrm{EMS}$ & $\mathrm{T}_{11}$ & $0.08 \%$ Colchicine \\
\hline $\mathbf{T}_{\mathbf{2}}$ & $3 \mathrm{~Gy}$ & $\mathrm{~T}_{7}$ & $0.55 \% \mathrm{EMS}$ & $\mathrm{T}_{12}$ & $0.10 \%$ Colchicine \\
\hline $\mathbf{T}_{\mathbf{3}}$ & $4 \mathrm{~Gy}$ & $\mathrm{~T}_{8}$ & $0.65 \% \mathrm{EMS}$ & $\mathrm{T}_{13}$ & $0.12 \%$ Colchicine \\
\hline $\mathbf{T}_{\mathbf{4}}$ & $5 \mathrm{~Gy}$ & $\mathrm{~T}_{9}$ & $0.75 \% \mathrm{EMS}$ & $\mathrm{T}_{14}$ & Control \\
\hline $\mathbf{T}_{\mathbf{5}}$ & $6 \mathrm{~Gy}$ & $\mathrm{~T}_{10}$ & $0.85 \% \mathrm{EMS}$ & & \\
\hline
\end{tabular}

\section{Results and Discussion}

\section{Sprouting percentage (\%)}

As the data presented in Table 1, it clearly showed that, concentration of gamma rays, EMS and Colchicine had significantly decreased the sprouting percentage of cloves over the control treatment $\mathrm{T}_{14}(31.73 \%)$. Further, it was also clear from the data that, the reduction in sprouting of cloves was increased with an increase in dose of gamma rays, EMS and Colchicine. Among the gamma rays and chemical mutagens, the significantly maximum sprouting percent was recorded $(30.67 \%)$ in the treatment $\mathrm{T}_{11}-0.08$ $\%$ colchicine and it was followed by the treatment $\mathrm{T}_{12}(30.13 \%) 0.10 \%$ colchicine, $\mathrm{T}_{1}$ $(29.20 \%) 2$ Gy and $\mathrm{T}_{13}(28.40 \%) 0.12 \%$ colchicine.

However, significantly minimum sprouting percentage of cloves were recorded in the treatment $\mathrm{T}_{10}(13.60 \%) 0.85 \%$ EMS and was followed by the treatment $\mathrm{T}_{9}(16.13 \%) 0.75$ $\%$ EMS 10 DAP of garlic cloves. 
Table.1 Effect of physical and chemical mutagens on sprouting percentage of garlic at 10 DAP

\begin{tabular}{|c|c|}
\hline Treatments & Sprouting percentage (\%) 10 DAP \\
\hline T1- 2 Gy & 29.20 \\
\hline T2- 3 Gy & 25.47 \\
\hline T3- 4 Gy & 23.60 \\
\hline T4- 5 Gy & 23.07 \\
\hline T5- 6 Gy & 18.93 \\
\hline T6- $0.45 \%$ EMS & 24.00 \\
\hline T7- $0.55 \%$ EMS & 20.93 \\
\hline T8- $0.65 \%$ EMS & 19.47 \\
\hline T9- $0.75 \%$ EMS & 16.13 \\
\hline T10- $0.85 \%$ EMS & 13.60 \\
\hline T11- $0.08 \%$ Colchicine & 30.67 \\
\hline T12- 0.10 \% Colchicine & 30.13 \\
\hline T13- 0.12 \% Colchicine & 28.40 \\
\hline T14- Control & 31.73 \\
\hline F test & Sig \\
\hline $\mathrm{SE}(\mathbf{m}) \pm$ & 0.16 \\
\hline CD at $5 \%$ & 0.47 \\
\hline
\end{tabular}

Table.2 Effect of physical and chemical mutagens on sprouting percentage of garlic at 20 DAP

\begin{tabular}{|l|c|}
\hline Treatments & Sprouting percentage (\%) 20 DAP \\
\hline T1- 2 Gy & 49.89 \\
\hline T2- 3 Gy & 47.87 \\
\hline T3- 4 Gy & 46.40 \\
\hline T4- 5 Gy & 45.07 \\
\hline T5- 6 Gy & 35.07 \\
\hline T6- 0.45 \% EMS & 47.07 \\
\hline T7- 0.55 \% EMS & 42.40 \\
\hline T8- 0.65 \% EMS & 38.40 \\
\hline T9- 0.75 \% EMS & 32.27 \\
\hline T10- 0.85 \% EMS & 29.07 \\
\hline T11- 0.08 \% Colchicine & 50.40 \\
\hline T12- 0.10 \% Colchicine & 50.13 \\
\hline T13- 0.12 \% Colchicine & 48.27 \\
\hline T14- Control & 52.93 \\
\hline F test & Sig \\
\hline SE $(\mathbf{m})$ 士 & 0.15 \\
\hline CD at 5\% & 0.43 \\
\hline
\end{tabular}


Table.3 Effect of physical and chemical mutagens on sprouting percentage of garlic at 30 DAP

\begin{tabular}{|l|c|}
\hline Treatments & Sprouting percentage (\%) 30 DAP \\
\hline T1- $\mathbf{~ G y}$ & 76.80 \\
\hline T2- 3 Gy & 71.20 \\
\hline T3- 4 Gy & 66.00 \\
\hline T4- 5 Gy & 65.33 \\
\hline T5- 6 Gy & 61.47 \\
\hline T6- 0.45 \% EMS & 70.13 \\
\hline T7- 0.55 \% EMS & 65.07 \\
\hline T8- 0.65 \% EMS & 62.40 \\
\hline T9- 0.75 \% EMS & 59.33 \\
\hline T10- 0.85 \% EMS & 55.73 \\
\hline T11- 0.08 \% Colchicine & 80.40 \\
\hline T12- 0.10 \% Colchicine & 79.33 \\
\hline T13- 0.12 \% Colchicine & 72.00 \\
\hline T14- Control & 93.20 \\
\hline F test & Sig \\
\hline SE $(\mathbf{m})$ 士 & 1.72 \\
\hline CD at 5\% & 5.00 \\
\hline
\end{tabular}

The results obtained at 20 DAP in Table 2, specified that, doses of gamma rays, EMS and Colchicine had significantly decreased the sprouting percentage of cloves over the control treatment $\mathrm{T}_{14}(52.93 \%)$. Further, it was also clear from the data that, the reduction in sprouting of cloves was increased with an increase in dose of gamma rays, EMS and Colchicine. Among the gamma rays and chemical mutagens, the significantly maximum sprouting percent was recorded $(50.40 \%)$ in the treatment $\mathrm{T}_{11}-0.08 \%$ colchicine and it was followed by the treatment $\mathrm{T}_{12}(50.13 \%) 0.10 \%$ colchicine, $\mathrm{T}_{1}$ (49.89\%) 2 Gy and $\mathrm{T}_{13}(48.27 \%) 0.12 \%$ colchicine. However, significantly minimum sprouting percentage of cloves was recorded in the treatment $\mathrm{T}_{10}(29.07 \%) 0.85 \%$ EMS and was followed by the treatment $\mathrm{T}_{9}(32.27$ $\%) 0.75 \%$ EMS 20 DAP of garlic cloves.

As the data presented in Table 3 at 30 DAP, it indicated that, concentration of gamma rays, EMS and Colchicine had significantly decreased the sprouting percentage of cloves over the control treatment $\mathrm{T}_{14}(93.20 \%)$. Further, it was also clear from the data that, the reduction in sprouting of cloves was increased with an increase in dose of gamma rays, EMS and Colchicine. Among the gamma rays and chemical mutagens, the significantly maximum sprouting percent was recorded $(80.40 \%)$ in the treatment $\mathrm{T}_{11}-0.08$ $\%$ colchicine and it was followed by the treatment $\mathrm{T}_{12}(79.33 \%) 0.10 \%$ colchicine, $\mathrm{T}_{1}$ (76.80\%) 2 Gy and $\mathrm{T}_{13}(72.00 \%) 0.12 \%$ colchicine. However, significantly minimum sprouting percentage of cloves was recorded in the treatment $\mathrm{T}_{10}(55.73 \%) 0.85 \%$ EMS and was followed by the treatment $\mathrm{T}_{9}(59.33$ \%) $0.75 \%$ EMS. Similar results were also studied by (Banjare et al., 2016)

This reduction in sprouting percent may be due to delay or inhibition of physiological and biological processes considered necessary for sprouting, including enzyme activity, hormonal imbalance, and inhibition of mitotic 
processes. Further, sprouting may be inhibited due to the toxic nature of the mutagen (Kumar et al., 2013), damage to cell constituents at the molecular level, or altered enzyme activity (Khan and Goyal, 2009).

In conclusion the sprouting percent decreased as the rate of concentration of mutagens increased. Based on the observation recorded at 10,20 and 30 days after planting, treatment $\mathrm{T}_{14}$ (Control) recorded maximum sprouting percentage followed by treatment $\mathrm{T}_{11}(0.08 \%$ Colchicine) and $\mathrm{T}_{12}(0.10 \%$ Colchicine $)$, whereas minimum sprouting percentage was recorded in $\mathrm{T}_{10}(0.85 \% \mathrm{EMS})$ followed by treatment $\mathrm{T}_{9}(0.75 \% \mathrm{EMS})$ and $\mathrm{T}_{5}(6 \mathrm{~Gy})$.

\section{References}

Agrawal, M. K., Fageria, M. S. and Dhake, R. S. 2003. Garlic breeding - a review. Agric. Rev. 24: 70-74.

Arora, S.D. and Kaur, J. 1999. Antimicrobial activity of spices. Internat. J. Antimicrobial Agents, 12(3): 257-262.

Banjare, C., Shukla, N., Sharma, P. K. and Shrivastava, R. 2016. Studies on Effect of Physical and Chemical Mutagens on Sprouting Characters in Garlic (Allium sativum L.) Genotypes. Advances in Life Sciences 5(22): 10459-10461.

Broertjes, C. and Harten, A. M. 1988. Applied mutation breeding for vegetatively propagated crops. Elsevier, Amsterdam, 34: 345-346.

Harris, J. C., Cottrell, S. L., Plummer, S. and Lloyd, D. 2001. Antimicrobial properties of Allium sativum L. (garlic). Application Microbiol. \& Biotechnol.,
57: 282-286.

Hughes, B.G. and Lawson, L.D. 1991. Antimicrobial effect of Allium sativum L. (garlic), Allium ampeloprasum (elephant garlic) and Allium cepa L. (onion), garlic compound and commercial garlic supplement products. Phytotherapy Res., 5(4): 154-158.

Khan, S. and Goyal, S. 2009. Improvement of mung bean varieties through induced mutations. Afr. J. Plant Sci. 3: 174-180.

Kumar, A., P., K., Boualem, A., Bhattacharya, A. and Parikh, S. 2013. SMART - sunflower mutant population and reverse genetic tool for crop improvement. BMC Plant Biol. 13: 38.

Mc Collum, G. D. 1976. Onion and allies. In: Evolution of Crop Plants (Ed. Simmonds, N.W.). Longman Press, New York, USA, pp. 186-190.

Meng, Y., Lu, D., Guo, N., Zhang, L. and Zhou, G. 1993. Anti- HCMV effect of garlic components. Virologica Sinica., 8: $147-150$.

Panse, N.G. and P. V. Sukhatme, 1967. New, Delhi, Directorate of Statistical methods for agricultural workers. Publication and Information, ICAR, pp. 157-167.

Reuter, H. D., Koch, H. P. and Lawson, L. D. 1996. Therapeutic effects and applications of garlic and its preparations. In: Garlic: The science and therapeutic applications of Allium sativum L. and related species (Eds. Koch, H.P. and Lawson, L.D.). Williams and Wilkins, Baltimore. pp. 135-213.

\section{How to cite this article:}

Pawar, A. P., V. S. Kale, P. K. Nagre, A. M. Sonkamble and Mane, S. S. 2020. Effect of Gamma Radiation, EMS and Colchicine on Sprouting in Garlic (Allium sativum L.). Int.J.Curr.Microbiol.App.Sci. 9(09): 3196-3200. doi: https://doi.org/10.20546/ijcmas.2020.909.395 